\title{
Unilateral Favre-Racouchot Disease: Evidence for the Etiological Role of Chronic Solar Damage
}

\author{
Sandra Vogel Michael Mühlstädt Sonja Molin Thomas Ruzicka Joseph Schneider \\ Thomas Herzinger
}

Klinik und Poliklinik für Dermatologie und Allergologie, Ludwig-Maximilians-Universität, Munich, Germany

\begin{abstract}
Key Words
Favre-Racouchot disease - Chronic solar damage $\cdot$ Chronic actinic damage $\cdot$ Solar elastosis · Cutaneous cysts · Smoking, adverse effects
\end{abstract}

\begin{abstract}
Favre-Racouchot disease commonly presents as comedones, cysts and elastosis in the periocular region of older men. Its etiology has been linked to several exogenous factors. Here we present 2 patients with strictly unilateral manifestation of the disease and a corresponding history of predominantly one-sided chronic occupational sun exposure and smoking, making the case for the causative role of these two factors.
\end{abstract}

Copyright $\odot 2013$ S. Karger AG, Basel

\section{Introduction}

In 1951, Favre and Racouchot originally described the coincidence of cysts, comedones and elastotic nodules on actinically damaged skin [1]. The condition is estimated to affect about $6 \%$ of Caucasian males beyond the age of 50 . Its pathogenesis is essentially unknown, but chronic exposure to sunlight and cigarette smoking are considered important triggers [2]. Here we present 2 patients with strictly unilat- eral manifestation of the disease, emphasizing the etiological role of chronic insolation.

\section{Case Report}

\section{Patient I}

A 72-year-old male patient reported a 7-year history of slowly expanding lesions on his left cheek. Examination revealed several dome-shaped ivory colored cysts of up to $6 \mathrm{~mm}$ in size and several comedones. Facial skin showed pronounced solar elastosis with yellowish discoloration and wrinkling (fig. 1). He had been smoking 20 cigarettes per day for the past 5 decades. Also, he had been working for 17 years as a doorman with the left side facing the lodge's window. The entire lesion was excised in two consecutive procedures at a 3-month interval. Histopathology revealed multiple cysts with enlarged infundibula with regularly stratified epithelium, surrounded by significant solar elastosis and atrophic sebaceous glands (fig. 2).

\section{Patient II}

A 69-year-old male patient had been aware of a lesion on his cheek for several years. Examination revealed an elastotic plaque with grouped yellowish cysts and comedones below his left eye (fig. 3). Re- cently he had cut down his smoking to 7 cigarettes per day but recalled having smoked a pack a day for many decades. As a truck driver he had been exposed to solar radiation predominantly through the left side window of his truck for more than 30 years. The lesion was excised with excellent cosmetic outcome. Histopathology revealed multiple cysts with enlarged infundibula with regularly stratified epithelium, surrounded by solar elastosis and atrophic sebaceous glands.

\section{Discussion}

Favre-Racouchot disease usually presents as symmetrical lesions of the periorbital or temporal area. Frequently it is combined with other signs of chronic sun damage such as cutis rhomboidalis nuchae. Differential diagnoses include colloid milium, milia, syringoma and trichoepithelioma. Chronic UV exposure and cigarette smoking have been implied as the most important etiological factors. An identical clinical picture has, however, been described after ionizing radiation [3]. $\mathrm{Re}$ markably, our patients presented only unilateral lesions. Korting [4] already described the case of an engine driver 'who showed such an "Elastéidose cutanée à kystes et à comédons" confined to the side

\section{KARGER}

E-Mail karger@karger.com

www.karger.com/drm (c) 2013 S. Karger AG, Base

1018-8665/13/2261-0032\$38.00/0
PD Dr. med. Thomas Herzinger

Klinik und Poliklinik für Dermatologie und Allergologie

Ludwig-Maximilians-Universität

Frauenlobstrasse 9-11, DE-80337 Munich (Germany)

E-Mail Thomas.Herzinger@med.uni-muenchen.de 

cysts on the left cheek of patient 1 (a) but not on his opposite cheek (b).
Fig. 1. Comedones and grotesquely sized
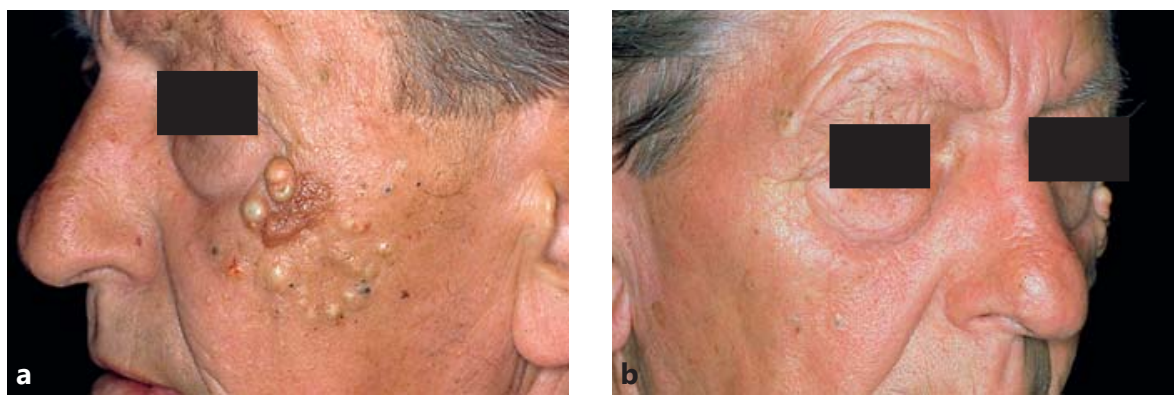

Fig. 2. Low-power overview (HE) demonstrates subepidermal elastosis and a noninflammatory cystic nodule. The cyst is filled with layered keratin. The number of sebaceous glands is decreased and the sebaceous glands shown (Inset $\times 20)$ appear rudimentary.

of his face which he exposed to the weather when looking out of the locomotive'. Three more cases were reported later, all of whom shared a history of prolonged unilateral sun exposure [5-7]. These observations support the notion of Favre and Racouchot that the disease does not simply represent a consequence of aging but is rather related to solar irradiation. Experimental support of this notion is rendered by a report on the induction of comedones by irradiation with either UVB or UVA1 in an individual with a previous history of Favre-Racouchot disease [8]. Epidermal inclusion cysts can also be induced by UVB treatment in hairless mice $[9,10]$. One study reported the prevention of such UVB-induced epidermal cysts in mice by treatment with red ginseng, an effect that the authors attributed to the antioxidant properties of ginseng [11].

A higher incidence of Favre-Racouchot disease was reported in smokers, and the likelihood to develop the disease correlated positively with the number of pack

years [12]. Apparently, sun exposure exerts an aggravating effect in smoking-induced cyst development: a retrospective study on 301 patients showed that a greater percentage of patients with abnormal inclusion cysts were smokers (50\%) than control subjects (27\%). This difference was significant only for cysts located in the face, while extrafacial locations did not differ in this regard [13]. This observation is supported by in vitro findings where the phototoxic properties of tobacco smoke were enhanced by ultraviolet light [14]. However, smoking per se has been reported to induce changes in elastic fibers similar to those observed following solar damage, with broader and more fragmented elastic fibers, even in areas of the body that are protected from insolation [15]. The particulate fraction of cigarette smoke contains many harmful carcinogenic constituents, including metals, polycyclic aromatic hydrocarbons, dioxins, and some nonvolatile nitrosamines [16]. Toxic doses of dioxins are known to induce 'chloracne',

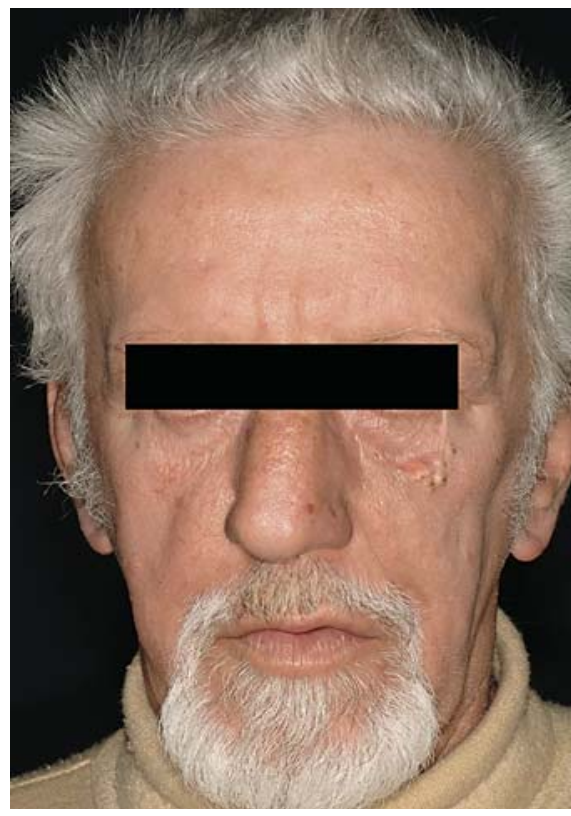

Fig. 3. Infraorbital plaque with comedones in patient 2 . 
a condition characterized by multiple epidermal cysts. The specific pathology of these exogenously induced cysts has been analyzed in detail recently [17]. Absence of sebaceous glands was one of the hallmarks of dioxin-induced cysts. The scarcity and atrophy of sebaceous glands found in $\mathrm{Fa}$ -
vre-Racouchot disease could suggest a similar yet less pronounced pathophysiology [18].

The treatment of Favre-Racouchot disease comprises the use of topical or systemic retinoids or surgical removal by dermabrasion, $\mathrm{CO}_{2}$ laser or excision.

\section{Disclosure Statement}

The authors have no conflicts of interest to declare.

\section{References}

-1 Favre M, Racouchot J: L'elastéidose cutanée nodulaire à kystes et à comédons. Ann Dermatol Syphiligr (Paris) 1951;78:681-702.

2 Plewig G, Kligman AM: Acne and rosacea. Berlin, Springer, 2000.

- 3 Breit S, Flaig MJ, Wolff H, Plewig G: FavreRacouchot-like disease after radiation therapy. J Am Acad Dermatol 2003;49:117-119.

4 Korting GW: Die Haut im Alter und ihre Krankheiten. Stuttgart, Schattauer, 1973.

5 Mavilia L, Rossi R, Cannarozzo G, Massi D, Cappugi P, Campolmi P: Unilateral nodular elastosis with cysts and comedones (FavreRacouchot syndrome): report of two cases treated with a new combined therapeutic approach. Dermatology 2002;204:251.

6 Moulin G, Thomas L, Vigneau M, Fiere A: Un cas unilateral d'élastose avec kystes et comédons de Favre et Racouchot. Ann Dermatol Venereol 1994;121:721-723.

7 Stefanidou M, Ioannidou D, Tosca A: Unilateral nodular elastosis with cysts and comedones (Favre-Racouchot syndrome). Dermatology 2001;202:270-271.
8 Hedelund L, Wulf HC: Favre-Racouchot disease provoked by UV-A1 and UV-B exposure. Arch Dermatol 2004;140:129-131.

-9 van Schanke A, van Venrooij GM, Jongsma MJ, Banus HA, Mullenders LH, van Kranen HJ, de Gruijl FR: Induction of nevi and skin tumors in Ink4a/Arf Xpa knockout mice by neonatal, intermittent, or chronic UVB exposures. Cancer Res 2006;66:2608-2615.

10 Yang G, Curley D, Bosenberg MW, Tsao H: Loss of xeroderma pigmentosum $\mathrm{C}(\mathrm{Xpc})$ enhances melanoma photocarcinogenesis in Ink4a-Arf-deficient mice. Cancer Res 2007; 67:5649-5657.

11 Lee HJ, Kim JS, Song MS, Seo HS, Moon C, Kim JC, Jo SK, Jang JS, Kim SH: Photoprotective effect of red ginseng against ultraviolet radiation-induced chronic skin damage in the hairless mouse. Phytother Res 2009;23:399403.

12 Keough GC, Laws RA, Elston DM: Favre-Racouchot syndrome: a case for smokers' comedones. Arch Dermatol 1997;133:796-797.
13 Lin SH, Yang YC, Chen W, Wu WM: Facial epidermal inclusion cysts are associated with smoking in men: a hospital-based case-control study. Dermatol Surg 2010;36:894-898.

14 Placzek M, Kerkmann U, Bell S, Koepke P, Przybilla B: Tobacco smoke is phototoxic. $\mathrm{Br}$ J Dermatol 2004;150:991-993.

15 Frances C, Boisnic S, Hartmann DJ, Dautzenberg B, Branchet MC, Charpentier YL, Robert $\mathrm{L}$ : Changes in the elastic tissue of the nonsun-exposed skin of cigarette smokers. $\mathrm{Br} \mathrm{J}$ Dermatol 1991;125:43-47.

16 Hammond D, O’Connor RJ: Constituents in tobacco and smoke emissions from Canadian cigarettes. Tob Control 2008;17(suppl 1):i24i31.

17 Saurat JH, Kaya G, Saxer-Sekulic N, Pardo B, Becker M, Fontao L, Mottu F, Carraux P, Pham XC, Barde C, Fontao F, Zennegg M, Schmid P, Schaad O, Descombes P, Sorg O: The cutaneous lesions of dioxin exposure: lessons from the poisoning of Victor Yushchenko. Toxicol Sci 2012;125:310-317.

18 Lever WF, Schaumburg-Lever G: Histopathology of the Skin, ed 7. Philadelphia, J.B. Lippincott, 1990. 